\title{
SCIENTIFIC REPORTS

\section{OPEN Hypoxic environment may enhance migration/penetration of endocrine resistant MCF7- derived breast cancer cells through monolayers of other non-invasive cancer cells in vitro}

\author{
Nora H. Barrak, Maitham A. Khajah \& Yunus A. Luqmani*
}

The response of cancer cells to hypoxic conditions found within the interior of a tumor mass is mediated through the hypoxia inducible factor (HIF) cascade and is thought to promote metastasis. However, given their distant proximity from blood vessels as compared to normoxic cells at the vascularised tumor periphery, it is uncertain if these cells can migrate through the tumor mass to gain access. Hypoxia was simulated by exposure to cobalt chloride or deferoxamine in normal (MCF10A) and cancerous [estrogen receptor (ER) - ve (pII), and ER + ve (YS1.2/ EII)] cells. In this report, HIF1 $\alpha$ expression and localization was measured using western blotting, ELISA, and immunofluorescence, cell proliferation by MTT assay, motility and invasion by wound healing, live cell imaging, matrigel and co-culture in chambered slides. We found that the expression and nuclear translocation of HIF1 $\alpha$ was significantly elevated by hypoxia, which inhibited cell proliferation, but significantly increased motility of pll cells and their penetration into and through a dense layer of adjacent Ell cells, as well as their selective emergence out of a co-culture. These data suggest that endocrine resistant pll cancer cells, having undergone epithelial to mesenchymal transition are able to penetrate through other cell layers, with possible enhancement in response to hypoxia.

Hypoxia is a state of low oxygen level, and represents a pernicious effect of diseases such as cardiovascular diseases, diabetes, dementia and cancer. It is variably observed in most if not all solid tumors, depending on the type, size and stage ${ }^{1}$ and develops as a result of expansion of tumor tissue due to increased proliferation of cancer cells with reduced oxygen supply especially in the core where there is considerable distance from the tumour-induced vasculature $^{2}$. This condition is correlated with poor prognosis as well as poor outcome of anti-cancer therapies ${ }^{3-5}$.

In the breast, hypoxia has been shown to induce genome-wide changes in DNA hydroxy-methylation that leads to the acquisition of breast tumor-initiating cell properties with up-regulation of tumor necrosis factor and activation of the p38-MAPK effector pathway ${ }^{6}$. Acute and chronic states of hypoxia can lead to variable outcomes in cancer cells ${ }^{7}$. Under conditions of acute hypoxia they adapt by decreasing reliance upon oxidative metabolism for energy generation, while increasing autophagy, reactive oxygen species (ROS) generation and metastasis, leading to tumor survival and progression ${ }^{8-12}$. Chronic hypoxia for a few hours to several weeks leads to high frequency of DNA breaks and accumulation of replication errors leading to genetic instability and mutagenesis ${ }^{13-15}$. Hypoxia also appears to be a driver of alternative splicing events in a large number of genes involved in multiple processes of tumorigenic development ${ }^{16}$.

The hypoxia-inducible factor (HIF) ${ }^{17}$, is considered to be the major downstream transcription factor activated in both hypoxic and non-hypoxic conditions by stimuli such as nitric oxide (NO), ROS, cytokines, lipopolysaccharide, G-protein coupled receptors and toll-like receptors ${ }^{18-21}$. In the presence of oxygen, HIF-1 $\alpha$ subunits are hydroxylated by oxygen-dependent enzymes such as prolulhydroxylases and factor inhibiting HIF- $1^{22}$ leading to poly-ubiquitination and proteasomal degradation of the $\alpha$ subunits ${ }^{23}$. Under hypoxic 
conditions, these oxygen-sensor enzymes lose their activity resulting in HIF-1 $\alpha$ protein stabilization, accumulation and translocation to the nucleus to dimerize with the constitutively expressed HIF- $1 \beta$ subunits to bind to target hypoxia-responsive elements and induce expression of genes involved in cell anaerobic metabolism, survival, metastasis, angiogenesis and drug resistance. These include VEGF, SDF-1, Ang-II, MMPs 2 and 9, BNIP-3, p53, E-cadherin, CXCR4, LOX, CAIX, GLUT-1, and GSK ${ }^{22,24-30}$. A recent study indicated that the TRAF6-H2AX- $\gamma \mathrm{H} 2 \mathrm{AX}$ - axis mediates HIF1 $\alpha$ enrichment in the nucleus of cancer cells leading to its stabilization and activation to enhance tumorigenesis, glycolysis and metastasis ${ }^{31}$. HIF-1- $\alpha$ was shown to be expressed in the majority of cancer biopsies at the leading edge of invading tumors ${ }^{32}$ and correlated with increased risk of metastasis and poor prognosis ${ }^{33-43}$.

Hypoxia can be stimulated in vitro by incubation in low oxygen environment using a specialized chamber, or by incubation with chemical agents. Exposure to cobalt chloride $\left(\mathrm{CoCl}_{2}\right)$ (which in vivo is a chelating agent replacing $\mathrm{Fe}^{2+}$ in hemoglobin, impairing the cell's reception of oxygen ${ }^{44,45}$ ) was shown to induce HIF-1 $\alpha$ expression in PC-2 human pancreatic cancer cells ${ }^{46}$. Deferoxamine (DFO), a bacterial sidephore that chelates iron and inhibits iron-dependent prolyl hydroxylases thus preventing the degradation of HIF isoforms in normoxic conditions ${ }^{47-49}$ has also been used to induce a state of hypoxia in vitro. Kilic and colleagues recently showed increased release of extracellular vesicles from MCF-7 breast cancer cells, due to $\mathrm{CoCl}_{2}$ induced hypoxia ${ }^{50}$. These are increasingly implicated in cancer progression through inter-cellular communication and transfer of mediators.

It seems to be generally held that hypoxic environment modulates various effector functions of cancer cells such as induction of epithelial to mesenchymal transition (EMT) ${ }^{51-53}$, and enhancement of cell proliferation ${ }^{45}$ and invasion ${ }^{54}$ which promotes tumour metastasis. This has led to the popular belief that metastasis is promoted by an acidic extracellular environment, which is expected to be found around anaerobically metabolizing cells producing and secreting excessive amounts of lactate (and by co-transport, $\mathrm{H}+$ ), i.e. the hypoxic cells. It has also been suggested that there may be a 'metabolic symbiosis' between hypoxic cells producing lactate and oxygenated cells utilizing it as a substrate to feed into their oxidative cycle. However, the obvious but apparently un-addressed anomaly here is two-fold. Firstly, the hypoxic cells are buried within the core of the tumour and would have to penetrate through a dense meshwork of more oxygenated cancer and normal cells to reach the tumour periphery to contact blood vessels. Secondly, it is the cells at the neo-vascularized normoxic surface of the tumour mass that are actively proliferating, and therefore logically may be expected to have greater opportunity to metastasise. So we are faced with this intriguing question - which cells in the tumour mass actually metastasise? Clearly this issue will not be easy to resolve and longer term may be best addressed by video imaging of tumours in vivo when this becomes possible.

In the current report it is intended to look at this question in the limited setting of an in vitro model that could provide some preliminary indications to address the questions posed above. Using the weakly-invasive estrogen receptor (ER) + ve MCF7 parental cells and the highly invasive ER silenced pII cells, we proposed to firstly examine their relative proliferative, motile and invasive abilities under normoxic/hypoxic conditions, comparing these also with normal MCF10A breast epithelial cells. Then, to try to simulate a tumor mass by mixing the different cells to determine whether they can penetrate through layers of each other before/after pre-treatment with HIF $1 \alpha$ inducing agents to simulate the conditions of hypoxia.

\section{Materials and Methods}

Cell lines. MCF10A (used in this study as a normal non-malignant breast cell line) was obtained from Dr E Saunderson St Bartholomews Hospital, London. MCF7 (estrogen receptor ER + ve breast cancer cells) were originally obtained from the ATCC (American Type Culture Collection, VA, USA). pII (ER - ve) and EII (ER + ve) are stable shRNA transfected cloned lines derived from the MCF7 line ${ }^{55}$. pII is ER-silenced while EII is a control line containing the shRNA carrying plasmid without ER down-regulation and constitutively expressing green fluorescent protein (GFP) as a marker. YS1.2 is MCF7 transfected with ER-directed shRNA but also failed to down-regulate $\mathrm{ER}$ and remained $\mathrm{ER}+\mathrm{ve}^{56}$.

MCF10A cells were cultured in DMEM F12 medium supplemented with 5\% horse serum, 1x Pen/Strep, $20 \mathrm{ng} / \mathrm{mL}$ EGF, $0.5 \mu \mathrm{g} / \mathrm{mL}$ hydrocortisone, $100 \mathrm{ng} / \mathrm{mL}$ cholera toxin and $10 \mu \mathrm{g} / \mathrm{mL}$ insulin. All other cell lines were routinely maintained at $37^{\circ} \mathrm{C}$ in a humidified atmosphere of $5 \% \mathrm{CO}_{2}$ in Dulbecco's modified eagle's medium (Advanced DMEM), supplemented with 5\% fetal bovine serum (FBS), $600 \mathrm{mg} / \mathrm{mL}$ L-glutamine, $100 \mathrm{U} / \mathrm{Ml}$ penicillin, $100 \mathrm{mg} / \mathrm{mL}$ streptomycin and $6 \mathrm{~mL} / 500 \mathrm{~mL} 100 \mathrm{x}$ non-essential amino acids. Cells were routinely grown in monolayer in 25 or $75 \mathrm{~cm}^{2}$ tissue culture flasks inside an incubator maintained at $37^{\circ} \mathrm{C}$ with $5 \% \mathrm{CO}_{2}$ atmosphere at $95 \%$ humidity.

Cell cultures were periodically treated with mycoplasma removal agent from Biorad (USA) and tested with detection kits from Invivogen (USA) and DAPI nuclear staining to ensure they remained free of mycoplasma.

Cell labeling. Qtracker 625 cell labeling kit (ThermoFisher Scientific, USA) was used to label pII cells (red dye) to monitor their motility. This was performed by mixing $1 \mu$ leach of solution $\mathrm{A}$ and $\mathrm{B}$ for 5 min followed by addition of $200 \mu \mathrm{L}$ DMEM and mixing with $1 \times 10^{6} \mathrm{pII}$ cells prior to incubation at $37^{\circ} \mathrm{C}$ in $5 \% \mathrm{CO}_{2}$ for $1 \mathrm{~h}$. Following this incubation, the media was discarded and replaced with fresh media. The dye has an excitation of $405-585 \mathrm{~nm}$ and emission of $625 \mathrm{~nm}$.

Western blotting. Cells were cultured in 6 well plates with complete DMEM to $80-90 \%$ confluence, and the medium was subsequently aspirated off and cell monolayers harvested by scraping and re-suspension into $300 \mu \mathrm{l}$ of lysis buffer containing $50 \mathrm{mM}$ HEPES, $50 \mathrm{mM} \mathrm{NaCl}, 5 \mathrm{mM}$ EDTA $1 \%$ Triton X, $100 \mu \mathrm{g} / \mathrm{ml}$ PMSF, $10 \mu \mathrm{g} /$ $\mathrm{ml}$ aprotinin, and $10 \mu \mathrm{g} / \mathrm{ml}$ leupeptin. Protein concentration was determined by the Bradford assay using BSA as standard, and $8 \mu \mathrm{g}$ protein lysate was mixed with an equal volume of $2 \mathrm{x}$ SDS and heated at $90^{\circ} \mathrm{C}$ for $10 \mathrm{~min}$. Samples were loaded onto a $10 \%$ SDS-polyacrylamide gel and electrophoresed at $150 \mathrm{~V}$ for $1 \mathrm{~h}$. Proteins were 
transferred to a nitrocellulose membrane and blocked with 2\% BSA for $1 \mathrm{~h}$ before being incubated overnight at $4^{\circ} \mathrm{C}$ with HIF $1 \alpha$ or actin (loading control) antibody (Cell Signaling, USA) (1:1000 dilution) prepared in $2 \%$ BSA. The membrane was washed and incubated with anti-HRP-conjugated secondary antibody (Cell Signaling, USA) (1:1000 dilution) for $1 \mathrm{~h}$, developed with Super Signal ECL and visualized with Kodak X-ray film.

Immunofluorescence. Cells were seeded at approximately 5000 cells/well in an 8-chambered slide containing $200 \mu \mathrm{l} /$ well DMEM media $\left(\mathrm{CO}_{2}\right.$ independent media) and allowed to settle for $48 \mathrm{~h}$. The media was then removed and replaced with media containing either Cobalt (II) chloride $\left(\mathrm{CoCl}_{2}\right)$ or Deferoxamine mesylate salt (DFO) (Sigma-Aldrich, USA) at $100 \mu \mathrm{M}$ and left for $30 \mathrm{~min}, 1 \mathrm{~h}, 4 \mathrm{~h}, 24 \mathrm{~h}$ and $48 \mathrm{~h}$ at which times cells were fixed by the addition of $3.7 \%$ formaldehyde for $10 \mathrm{~min}$ and washed with ice-cold PBS. Cells were treated with $1 \%$ BSA and then incubated with HIF $1 \alpha$ antibody (1:80 dilution) overnight at $4{ }^{\circ} \mathrm{C}$. Unbound primary antibody was aspirated, cells washed with ice-cold PBS and incubated with anti-rabbit secondary antibody (1:250 dilution). Excess unbound secondary antibody was aspirated off, cells were washed with ice-cold PBS, fixed and stained with phalloidin (Thermo-fisher, USA) (1:125 dilution) to stain for F-actin and DAPI to stain the nucleus. After removal of the silicone scaffolding and mounting, cells were examined under a confocal microscope (Carl Zeiss, Germany) at an excitation wavelength of $450 \mathrm{~nm}$ and images analyzed and processed using a ZEISS software package.

MTT assay. Cells were seeded into 24-well culture plates and allowed to grow to $30-35 \%$ confluency. The medium was removed and replaced with medium containing $100 \mu \mathrm{M} \mathrm{CoCl}_{2}$ or DFO or vehicle, and cell quantity determined either immediately (day zero) or after 1 day and 4 days of growth. For the measurement, medium was removed and replaced with $500 \mu \mathrm{l}$ of MTT reagent (Sigma-Aldrich, USA) $(0.5 \mathrm{mg} / \mathrm{ml})$ and left at $37^{\circ} \mathrm{C}$ for $2 \mathrm{~h}$; MTT solution was removed and $200 \mu \mathrm{l}$ of acidic isopropanol added to dissolve the blue formazan crystals. Plates were scanned at 595 and $650 \mathrm{~nm}$ using a MULTISKAN SPECTRUM spectrophotometer.

Motility assay. Cells were grown to $90 \%$ confluency in 12 well plates, and treated with vehicle $\left(\mathrm{dH}_{2} \mathrm{O}\right)$, or various concentrations $(25-100 \mu \mathrm{M})$ of $\mathrm{CoCl}_{2}$ or DFO. A fine scratch was made using a sterile yellow $200 \mu \mathrm{l}$ Eppendorf pipette tip through the center of the YS1.2 cell monolayer and $1000 \mu \mathrm{l}$ tip for pII and MCF10A cell monolayers. The width of the scratch was recorded under phase contrast light microscopy immediately $(0 \mathrm{~h})$ and after $24 \mathrm{~h}$ of incubation to determine the extent of wound closure.

Live cell imaging. Relative movements of the different cell lines were studied using an Ibidi $\mu$ chamber plate (Ibidi, Germany) which allows segregated cultivation of cells. Non-invasive EII cells, which have intrinsic green fluorescence due to expression of GFP, and the highly invasive pII cells (previously labeled with the Qtracker red dye) were grown in adjacent chambers of an Ibidi plate $\left(1 \times 10^{4}\right.$ cells in $100 \mu$ of DMEM media) at $37^{\circ} \mathrm{C}, 5 \% \mathrm{CO}_{2}$ overnight to attach. On the following day, the spacer between the cells was removed and $2 \mathrm{ml}$ of $\mathrm{CO}_{2}$ independent culture media (to maintain $\mathrm{pH}$ at 7.4) was added and the slide placed inside an imaging chamber (Cell Observer HS, ZEISS) heated to $37^{\circ} \mathrm{C}$ with an airstream. Live cell microscopy with time-lapse photography, was used to continuously monitor the migration of cells (pII and EII) into their opposite compartment. For this, the plate was positioned to enable photography of both cells on the edges and an empty space in the middle and images (at 10 $\mathrm{x}$ magnification) were taken every $10 \mathrm{~min}$. The AxioVision software (ZEISS) was used to combine all the pictures to generate a video.

Cell invasion through a single layer of basement membrane extract. The upper inset chambers of a Cultrex assay dish were coated with $100 \mu \mathrm{l}$ of $1 \mathrm{x}$ basement membrane extract (BME) solution and incubated overnight at $37^{\circ} \mathrm{C}$. Meanwhile, cells (treated with vehicle, or $100 \mu \mathrm{M} \mathrm{CoCl} \mathrm{Cr}_{2}$ ofO) were serum starved overnight at $37^{\circ} \mathrm{C}$ and $5 \% \mathrm{CO}_{2}$. On the following day, cells were harvested and re-suspended in serum free media and $100 \mu \mathrm{l}$ containing $10^{5}$ cells were added into the upper chamber. The lower chamber was loaded with $500 \mu \mathrm{l}$ of serum free media (negative control) or media containing $40 \% \mathrm{FBS}$ as a chemo-attractant. Cells were incubated at $37^{\circ} \mathrm{C}, 5 \% \mathrm{CO}_{2}$ and allowed to invade from the top to the bottom chamber. After $48 \mathrm{~h}$, the media was aspirated from the upper chamber and the bottom washed with $1 \mathrm{x}$ cell washing buffer. Calcein-AM/cell dissociation solution was added to the bottom chamber and left for $1 \mathrm{~h}$ at $37^{\circ} \mathrm{C}, 5 \% \mathrm{CO}_{2}$. Cells present in the bottom chamber were quantitated by their ability to internalize Calcein-AM, with intracellular esterases cleaving the acetomethylester (AM) moiety generating free fluorescent calcein which could then be determined by recording the fluorescence emission using a microplate reader with a filter set of Excitation/Emission $=485 / 535 \mathrm{~nm}$ (CULTREX, 2008).

Cell invasion through a two-layer system composed of cells and BME. The Cultrex inset chamber was coated with 1x BME and left to set overnight as previously described. On the next day, serum starved EII cells were re-suspended in serum free media and $100 \mu$ of cells $\left(10^{5}\right)$ were added into the upper chamber and allowed to settle at $37^{\circ} \mathrm{C}$ overnight. Then, $100 \mu$ of pII cells $\left(10^{5}\right)$ that had been $24 \mathrm{~h}$ serum starved either in the absence (control) or presence of $100 \mu \mathrm{M} \mathrm{CoCl}_{2}$ overnight at $37^{\circ} \mathrm{C}$ and $5 \% \mathrm{CO}_{2}$ and re-suspended in serum free media were added to form a layer on top of the EII cells. The plate was then left overnight at $37^{\circ} \mathrm{C}$ in $5 \% \mathrm{CO}_{2}$ and procedure followed as already described above.

Under-agarose migration assay. Ultra-pure agarose (Invitrogen, USA) ( $0.18 \mathrm{~g}$ ) was dissolved by boiling

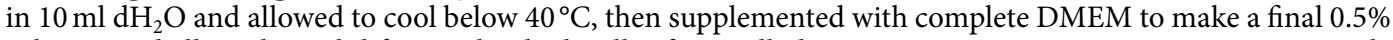
solution and allowed to solidify in individual wells of a 6 well plate at room temperature. Once set, 1-2 sample chambers ( $3.5 \mathrm{~mm}$ in diameter) were created in the gel, $2.5 \mathrm{~mm}$ apart in a horizontal line, by insertion of a metallic mold as described previously ${ }^{57}$. Suspensions of PII and YS1.2 cells $\left(4 \times 10^{4}\right)$ in DMEM containing 5\% FBS, that had previously been exposed for $24 \mathrm{~h}$ to $\mathrm{CoCl}_{2}$ or DFO $(100 \mu \mathrm{M})$ or to vehicle only were loaded into the formed 
chambers. Plates were incubated at $37^{\circ} \mathrm{C}$ in $5 \% \mathrm{CO}_{2}$ humidified atmosphere. After $24 \mathrm{~h}$, cells that had penetrated the agarose were manually counted by visual microscopic examination as previously described ${ }^{57}$.

Ibidi invasion assay. To monitor the migration/invasion of labeled pII cells towards EII cells, $1 \times 10^{4}$ cells suspended in $100 \mu \mathrm{l}$ of DMEM were grown in separate compartments of an Ibidi chamber plate. The plate was incubated at $37^{\circ} \mathrm{C}, 5 \% \mathrm{CO}_{2}$ overnight. On the next day, the spacer between the cells was carefully removed and replaced with $2 \mathrm{ml}$ of DMEM containing $\mathrm{CoCl}_{2}$ or DFO $(100 \mu \mathrm{M})$ or vehicle (control). The number of pII cells migrating/invading through EII cells in all the conditions was recorded under phase contrast and fluorescence light microscopy immediately after removing the spacer and at various intervals thereafter (24-96h).

Ibidi invasion assay with co-cultured cells. To monitor the migration of labeled pII cells out of a co-culture with EII cells, the two cell cultures $\left(1 \times 10^{4}\right)$ suspended in $100 \mu$ lof DMEM were mixed together in different proportions (EII:pII; $1: 1$ and 4:1) in an Ibidi chamber plate. The plate was incubated at $37^{\circ} \mathrm{C}, 5 \% \mathrm{CO}_{2}$ overnight. On the next day, the spacer was removed and medium replaced with $2 \mathrm{ml}$ DMEM containing $\mathrm{CoCl} 2$ $(100 \mu \mathrm{M})$ or vehicle. The number of pII cells moving/invading out of the mixture was recorded as previously described.

Statistical analysis. Difference between mean values of tested groups was analyzed by the student's t-test or one-way ANOVA followed by Bonferroni post-hoc test using GraphPad Prisim 5. P $<0.05$ was considered statistically significant.

\section{Results}

Effect of hypoxic simulation with $\mathrm{CoCl}_{2}$ and DFO on HIF-1 $\alpha$ expression in normal and cancerous breast epithelial cells. The optimal concentration for induction of HIF-1 $\alpha$ was found to be $100 \mu \mathrm{M}$ for both $\mathrm{CoCl}_{2}$ and DFO and this was used for subsequent experiments. Using an ELISA-based technique, HIF-1 $\alpha$ protein levels were determined in untreated (control) cells and at various times $(0.5-48 \mathrm{~h})$ after addition of $\mathrm{CoCl}_{2}$ or DFO. As shown in Fig. 1A-C, the baseline level of HIF1 $\alpha$ in untreated control MCF10A cells $(40 \pm 4.34 \mathrm{pg} /$ $\mathrm{ml})$, was much lower than that in both ER +ve $(300 \pm 32.03 \mathrm{pg} / \mathrm{ml})$ or ER-ve $(1000 \pm 59.21 \mathrm{pg} / \mathrm{ml})$ breast cancer cells. In all cases, HIF1 $\alpha$ levels reached a maximum by $24 \mathrm{~h}$ of treatment and declined thereafter. The $\mathrm{CoCl}_{2}$ induced level of HIF $1 \alpha$ observed in the ER-ve pII cells after $24 \mathrm{~h}$ was of four-fold greater magnitude than that seen in MCF10-A and YS1.2 cells. But interestingly the relative increase in HIF1 $\alpha$ from the untreated control was approximately 26-30 fold in MCF10A cells and only 3-4 fold in the cancer cells. The effect of DFO was also tested on pII cells and was found to be similar to that of $\mathrm{CoCl}_{2}$ (Fig. 1D). Western blot analysis was also performed to confirm the data obtained using ELISA (Fig. 1E).

Effect of hypoxia simulation on HIF-1 $\alpha$ localization. The distribution pattern of HIF $1 \alpha$ was determined by immunofluorescence in response to $\mathrm{CoCl}_{2}$ or DFO treatment $(100 \mu \mathrm{M})$ at $30 \mathrm{~min}$ to $48 \mathrm{~h}$. Cells were fixed and labeled with HIF1 $\alpha$ antibody, phalloidin (to visualize F-actin) and DAPI (nuclear stain). Treatment of MCF10A cells with either $\mathrm{CoCl}_{2}$ (Fig. 2A) or DFO (Fig. 2B) showed peri-nuclear expression of HIF-1 $\alpha$ at $4-48 \mathrm{~h}$ with no detectable expression at earlier times $(0.5-1 \mathrm{~h})$. In regard to YS1.2 cells (Fig. 3), peri-nuclear HIF-1 $\alpha$ expression was induced in response to $\mathrm{CoCl}_{2}$ (A) or DFO (B) treatment at earlier times $(0.5-4 \mathrm{~h})$ while nuclear expression peaked at $24 \mathrm{~h}$. In regard to $\mathrm{pII}$ cells (Fig. 4), peri-nuclear and cytoplasmic expression of HIF-1 $\alpha$ was induced at earlier times $(0.5-4 \mathrm{~h})$ in response to $\mathrm{CoCl}_{2}$ (A) or DFO (B) treatment but at 24-48 h of stimulation HIF- $1 \alpha$ was detected in the nucleus. Due to its poor immunoreactivity (possibly due to low expression) HIF $1 \alpha$ staining in all the figures (Figs. 2-4) was digitally enhanced in order to assess its cellular localization.

Effect of hypoxic simulation on cell proliferation. The effect of $\mathrm{CoCl}_{2}$ or DFO $(100 \mu \mathrm{M})$ treatment on cell proliferation was assessed using the MTT assay. As shown in Fig. 5, treatment with $\mathrm{CoCl}_{2}$ or DFO decreased proliferation of both normal (MCF10A) as well as the cancerous cells (YS1.2 and pII). This inhibition was seen at $24 \mathrm{~h}(\mathrm{~A}-\mathrm{C})$ and maintained at $96 \mathrm{~h}$ (D-F). The effect was more profound in the cancerous cells particularly at the shorter time and was also more pronounced with DFO. As this was somewhat unexpected, and to ensure that the results were not due to any impairment in mitochondrial function (at least in the enzymes involved in the MTT conversion) we also performed a proliferation assay with manual cell counting using a haemocytometer and found similar results (data not shown) to using the MTT assay.

Effect of hypoxic simulation on breast cancer cell motility. Wound healing (scratch) assay was used to determine the effect of hypoxic simulation on the motility of ER + ve and ER - ve breast cancer cells. As illustrated in Fig. 6, both $\mathrm{CoCl}_{2}$ and DFO treatment significantly increased YS1.2 (A) and pII (B) cell motility with maximal effect at $100 \mu \mathrm{M}$. It should be noted that the scratch in YS1.2 was made with a yellow tip as compared to a blue tip for the pII scratch creating a much wider gap. Hence the actual movement (as opposed to \% closure) of YS1.2 is much less than for pII. We also examined motility of MCF10A cells and surprisingly found that they were highly motile. As their culture medium contains stimulatory additives, we repeated the experiments omitting EGF in one case and in another, replacing the medium (24h prior) with the DMEM medium used for the cancer cells. The data (Supplementary Fig. 2) showed motility only in the complete MCF10A medium with no or little movement in the other two media. The presence of either DFO or $\mathrm{CoCl}_{2}$ however, stimulated significant dose dependent motility in all three media.

Effect of hypoxia on migration and invasion of breast cancer cells. The effect of hypoxia on random migration of ER + and ER - breast cancer cells was assessed using the agarose assay. Both YS1.2 and pII cells were pre-treated with either vehicle (control) or $\mathrm{CoCl}_{2} / \mathrm{DFO}$. As shown in Fig. $7 \mathrm{~A}$, pII cells were far more migratory 

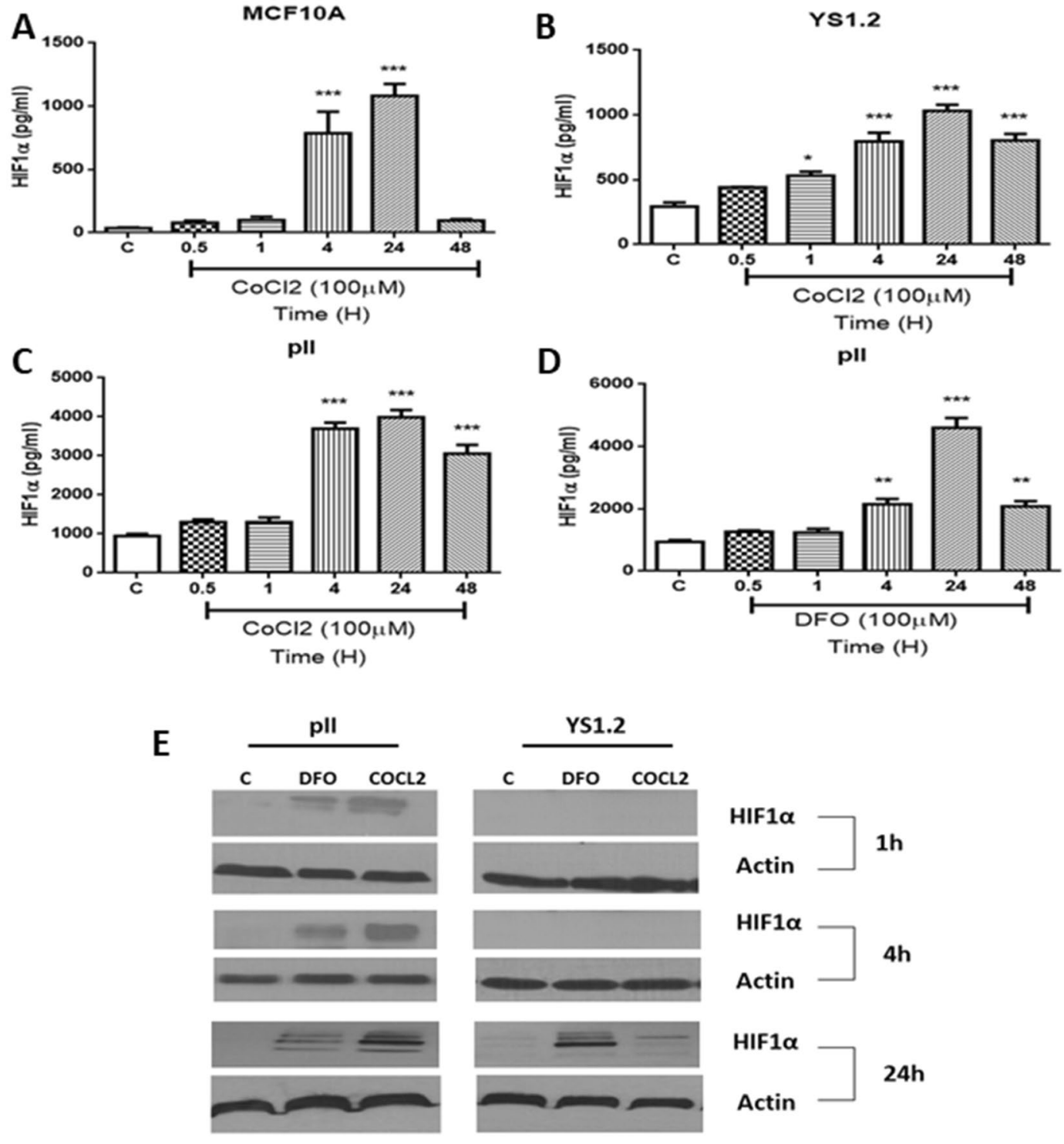

1h

4h

Figure 1. Effect of $\mathrm{CoCl}_{2}$ and DFO treatment on HIF-1 $\alpha$ expression. (A), normal breast epithelial cells MCF10A (B), estrogen receptor (ER) positive YS1.2 and (C,D), ER-negative pII breast cancer cells either untreated (control, open bars) or treated with $\mathrm{CoCl}_{2}$ or DFO $(100 \mu \mathrm{M}$, hatched bars). HIF-1 $\alpha$ was measured in the cell lysate by ELISA at times indicated as described in Methods. Histobars represent the mean \pm SEM of 3 independent determinations. Asterisks denote significant difference from the control, with $(*) p>0.05,(* *)$ $\mathrm{p}=0.01$, and $(* * *) \mathrm{p}=0.001$. Panel (E) Western blot analysis of HIF-1 $\alpha$ in breast cancer cells, which were either untreated (control) or treated with $\mathrm{CoCl}_{2}$ or DFO $(100 \mu \mathrm{M})$ and HIF-1 $\alpha$ determined at the times indicated. Protein lysates were electrophoresed in $10 \%$ SDS-polyacrylamide gel and blotted onto nitrocellulose membrane which was then cut into narrow strips (in the region of expected bands) and individually probed with antisera to HIF $1 \alpha$ (bands were detected at a molecular weight of $120 \mathrm{kDa}$ which corresponds to the expected HIF $1 \alpha$ size), or to $\beta$-actin, used as loading control.

when compared to YS1.2 as previously reported ${ }^{57}$, and $\mathrm{CoCl}_{2} / \mathrm{DFO}$ treatment did not significantly increase the number of cells migrating out of the well into the agarose. The low migratory capacity of YS1.2 cells was not influenced by either drug.

The Cultrex BME cell invasion assay was also used to assess the effect of hypoxic simulation on invasion of YS1.2 and pII cells. In this assay, both YS1.2 and pII cells were pre-treated with vehicle or $\mathrm{CoCl}_{2} / \mathrm{DFO}$ for $24 \mathrm{~h}$ and then loaded into the top chamber separated from the bottom chamber containing medium supplemented with $40 \%$ serum as a chemo-attractant. Cells invading into the lower chamber were assessed after $24 \mathrm{~h}$. Figure $7 \mathrm{~B}$ shows that ER - ve cells were 10 fold more invasive (note difference in Y axes) when compared to ER + ve cells; $\mathrm{CoCl}_{2} / \mathrm{DFO}$ treatment did not significantly increase cell invasion of either through the BME layer.

Live cell microscopy was also used to monitor the movement of ER - ve (pII, right side) and ER + ve (EII, GFP-tagged, left side) breast cancer cells co-cultured in an Ibidi chamber plate under normal conditions. As shown in Fig. 7C, within the first $6 \mathrm{~h}$, pII cells had moved towards the EII cell population and completely closed 


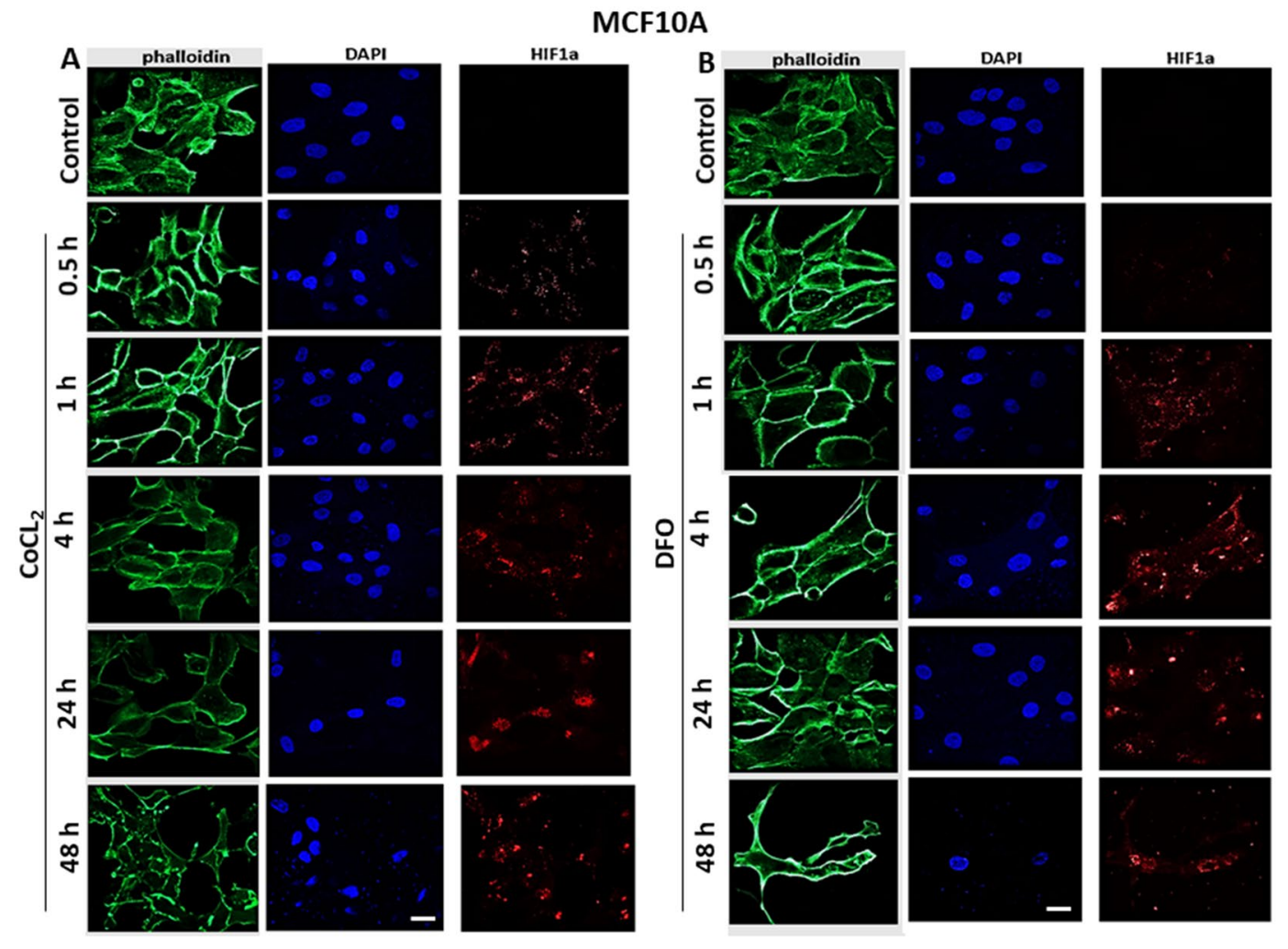

Figure 2. Effect of $\mathrm{CoCl}_{2}$ or DFO treatment on HIF-1 $\alpha$ localization in normal breast epithelial cells. MCF10A cells were seeded in 8 -chamber Ibidi slides and allowed to grow for $48 \mathrm{~h}$ at $37^{\circ} \mathrm{C} / 5 \% \mathrm{CO}_{2}$. Cells were either untreated (control) or treated with $(\mathbf{A}) \mathrm{CoCl}_{2}$ or $(\mathbf{B}) \mathrm{DFO}(100 \mu \mathrm{M})$ for times indicated. Cells were then fixed and stained with HIF1 $\alpha$ antibody (red), phalloidin (green, to stain F-actin cytoskeleton), and DAPI (blue, to stain the nucleus), 20x magnification. Scale bar represents $20 \mu \mathrm{m}$.

the gap between the two cell populations by $27 \mathrm{~h}$. The time lapse film (supplementary file) shows very clearly that the EII cells did not move towards the pII cells. However, with the optical instruments at our disposal, we were unable to determine whether the pII cells were able to invade further into the EII cell monolayer since we could not distinguish between the two cell populations despite that the EII cells were fluorescently labelled with GFP.

In order to study this phenomenon further and confirm whether pII cells can invade through a layer of another cancer cell type such as EII cells which are not or much less motile, pII cells were labeled with red dye and grown in an Ibidi chamber plate in a well adjacent to another containing a population of EII cells (green-labeled due to intrinsic GFP expression) and snap shots taken in phase contrast and fluorescence mode at $24 \mathrm{~h}$ intervals. In the first experiments we used lower confluency (about 60\%) of EII cells (data not shown) and found that many pII cells were present inside the EII layer possibly because there was empty space so we increased EII cells to $80 \%$ confluency to test whether pII cells are able to penetrate a more solid barrier of another cell line. As shown in Fig. 8A, two confluent monolayers of pII cells (right panel, red label) and EII cells (left panel, green label) were established and after 3 days, pII cells started to invade the EII population with about 10 cells present inside the EIImonolayer. On the third day of the co-culture, a few pII cells also penetrated beyond the EII layer. No EII cells were observed inside the pII monolayer. Following on from the previous experiment we wished to determine whether hypoxic conditions would alter the observed behaviour of the pII and EII cells (Fig. 8B). Thus we set up the same experiment as described above (Fig. 8A) but in the presence of $\mathrm{CoCl}_{2}$ or DFO; snap shots were taken using phase contrast and fluorescence mode every $24 \mathrm{~h}$. As shown in Fig. 8B, after $24 \mathrm{~h}$ of exposure under hypoxic conditions $\left(\mathrm{CoCl}_{2}\right)$, pII cells started to move towards the EII monolayer and closed the space between them. On day 2, pII cells began to invade into the EII population, and at day 3 some pII cells penetrated through the EII monolayer. This was also observed with DFO treatment (data not shown). There was a 2 -fold increase in the number of pII cells invading the EII monolayer under hypoxic conditions as compared to normoxia (Fig. 8D). Although there was a trend (this did not reach statistical significance) in the number of cells penetrating through the EII layer (Fig. 8E). There was no movement of EII cells towards the pII cell monolayer.

Having observed that pII cells could move into and through a layer of EII cells, we wished to determine how these cells would behave if cultured as a mixed population in both normoxic as well as hypoxic conditions as might be expected within a tumor mass. For this, pII cells were labeled with red dye and grown in an Ibidi chamber plate with EII cells under normoxic condition or in the presence of $\mathrm{CoCl}_{2}$. Two experimental settings were performed; a), with an equal ratio of ER + ve and ER - ve cells (data not shown) and b), with ER + ve: ER - ve cells at a ratio of 4:1 (Fig. 9). Under normoxic conditions pII cells were able to migrate out of the mixed population into the surrounding empty space. This was more pronounced when the density of both cell populations was equal 


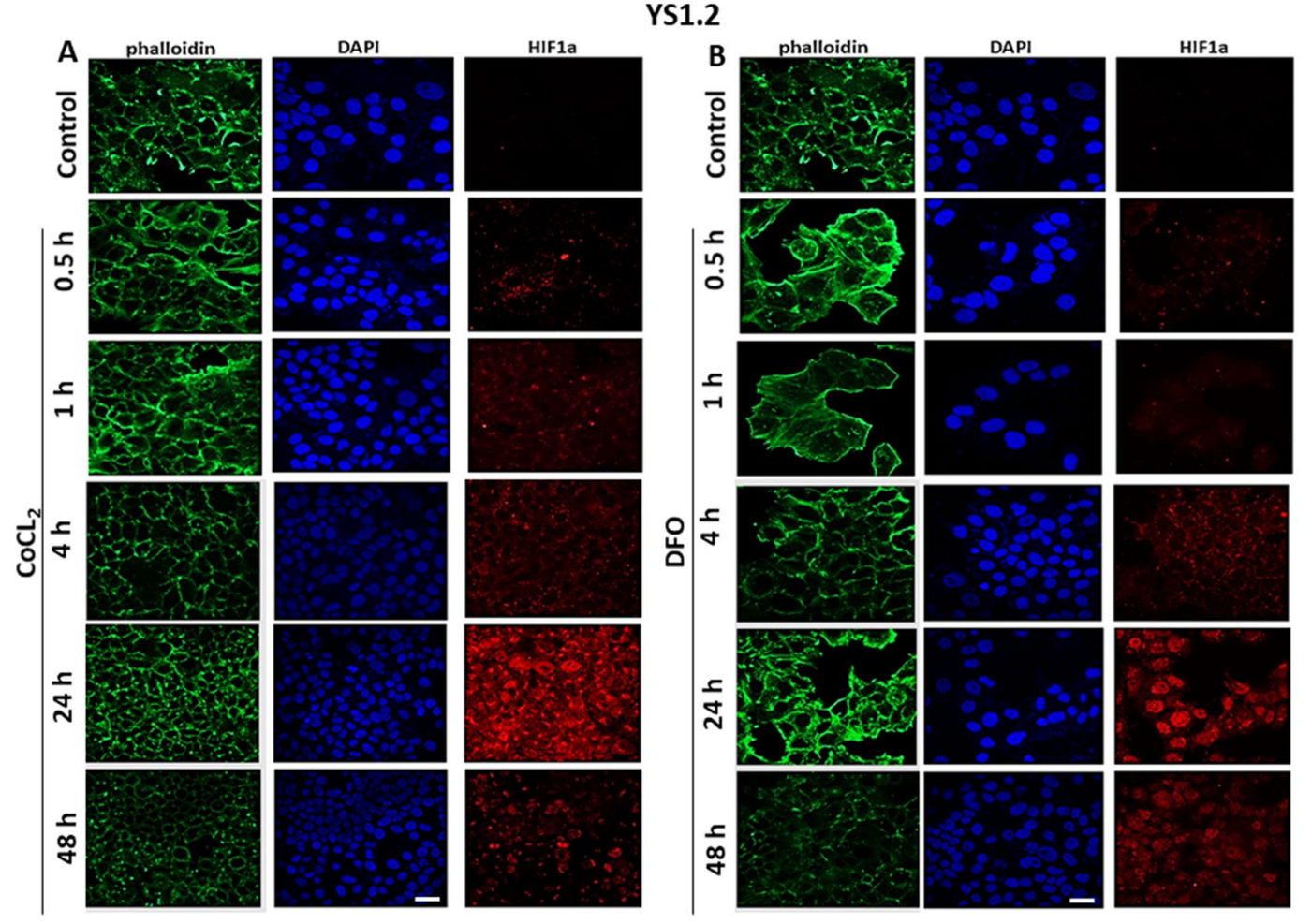

Figure 3. Effect of $\mathrm{CoCl}_{2}$ or DFO treatment on HIF- $1 \alpha$ localization in ER + ve breast cancer cells. YS1.2 cells were seeded in 8 -chamber Ibidi slides and allowed to grow for $48 \mathrm{~h}$ at $37^{\circ} \mathrm{C} / 5 \% \mathrm{CO}_{2}$. Cells were either untreated (control) or treated with $(\mathbf{A}) \mathrm{CoCl}_{2}$ or $(\mathbf{B}) \mathrm{DFO}(100 \mu \mathrm{M})$ for times indicated. Cells were then fixed and stained with HIF1 $\alpha$ antibody (red), phalloidin (green, to stain F-actin cytoskeleton), and DAPI (blue, to stain the nucleus), 20x magnification. Scale bar represents $20 \mu \mathrm{m}$.

compared to when there were fewer pII cells having to migrate through a higher density of EII cells. In the presence of $\mathrm{CoCl}_{2}$ the number of pII cells migrating out of the mixed population increased about two-fold (Fig. 9D). Unfortunately, the photographs do not show the proportion of the two cell populations correctly because the red fluorescence overpowers the green; however, in day 2, since the pII cells moved, the green fluorescence is more distinct from the red.

The Cultrex BME transwell cell invasion system was used to determine whether pII cells could invade through a layer of both EII cells and BME towards serum components. pII cells pre-incubated for $24 \mathrm{~h}$ with vehicle (control, normoxia) or with $100 \mu \mathrm{M} \mathrm{CoCl}_{2}$ (hypoxia) were loaded into the top chamber of a transwell plate in which EII cells had previously been seeded on top of a BME layer. After $24 \mathrm{~h}$ incubation, only pII cells were found in the lower chamber but the number of these was not significantly different whether pre-exposed to vehicle or $\mathrm{CoCl}_{2}$. Moreover, the number of penetrating cells was far fewer than seen in a parallel set-up in which the upper chamber was seeded with a similar number of cells in the absence of EII cells, giving direct contact with the BME layer (Fig. 10). However, it should be noted that the number of invading pII cells through the double barrier of EII/ BME were still significantly higher than the number of YS1.2 invading through a single layer of BME (Fig. 7B, upper panel).

\section{Discussion}

An important feature of metastasis is that it appears to involve individual or small groups of cells detaching from the tumor mass and therefore the further question arises - which cells from within the tumor metastasize? Is this a random process or does it involve specific cells? Is it the cells at the tumor periphery or those further inside? Neo-vascularisation of a growing tumor mass is disorganized and incomplete, such that the microenvironment of cells nearer to the core is more hypoxic compared to the cells at the periphery, and this phenomenon may be a major factor in cancer progression and metastasis ${ }^{6}$. It has been reported that hypoxic cells are highly invasive ${ }^{58,59}$, so could these be the cells that metastasize from a tumor? This would entail migration into and possibly through the upper layers of cancer cells that remain adherent, in order to intravasate into physiologically functional blood vessels most likely located at the tumor periphery.

HIF $1 \alpha$ is generally over-expressed under hypoxic conditions to regulate expression of downstream genes leading to enhanced cell motility and invasion ${ }^{60}$. HIF $1 \alpha$ protein and mRNA levels were elevated in human pancreatic cancer cells in response to $(100-200 \mu \mathrm{M}) \mathrm{CoCl}_{2}$ treatment for $0-12 \mathrm{~h}$ in a time and dose dependent manner ${ }^{46}$. Also, Chan et al. ${ }^{13}$ demonstrated enhanced HIF-1 $\alpha$ expression in human lung carcinoma cell lines grown in low $\mathrm{O}_{2}$ conditions. DFO treatment (30-300 $\mu \mathrm{M}$ for $24 \mathrm{~h}$ ) of MDA-MB-231 cells enhanced HIF1 $\alpha$ protein expres$\operatorname{sion}^{61}$. In this study, we showed that HIF1 $\alpha$ expression in response to $\mathrm{CoCl}_{2}(100 \mu \mathrm{M})$ treatment was significantly 


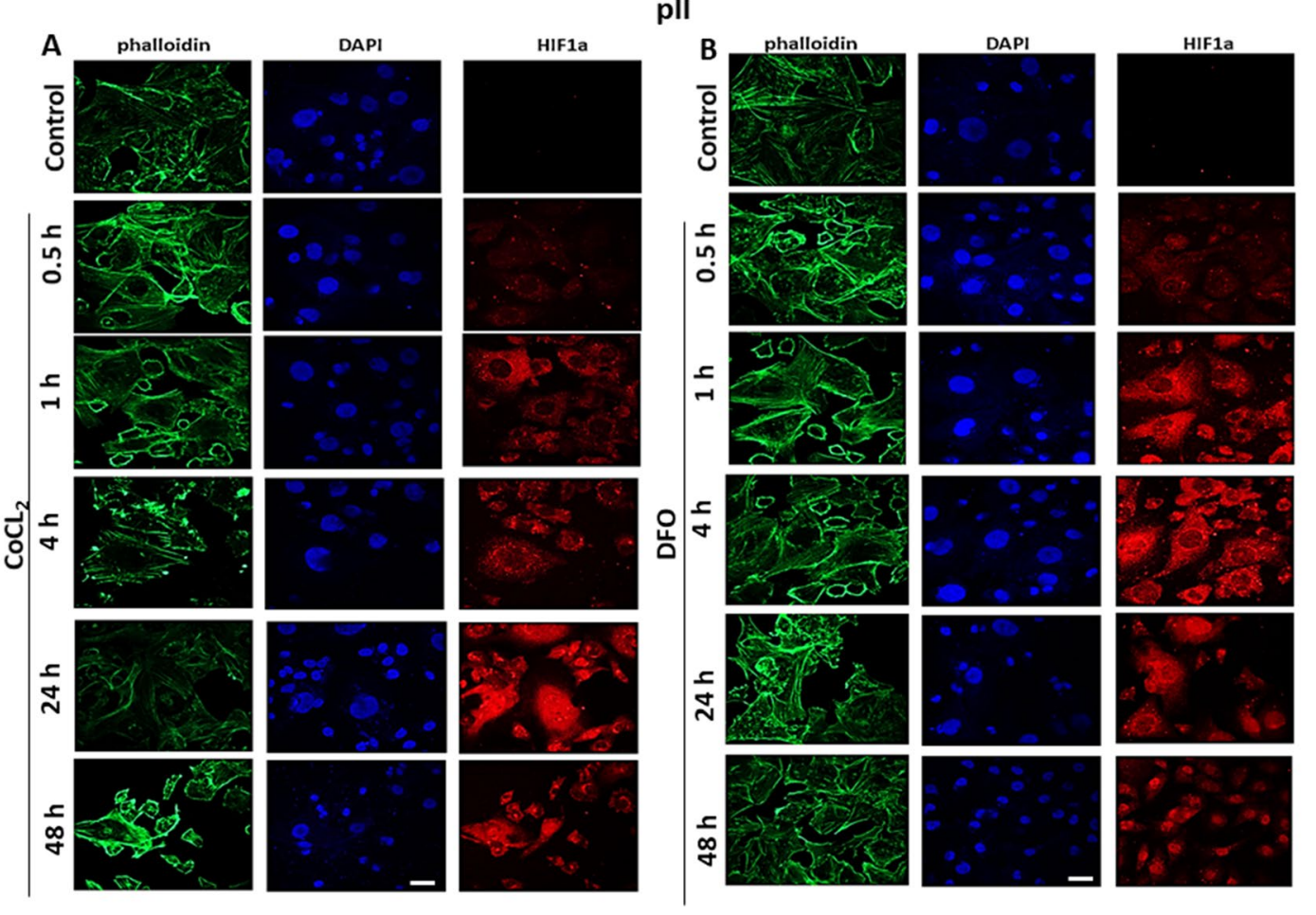

Figure 4. Effect of $\mathrm{CoCl}_{2}$ or DFO treatment on HIF-1 $\alpha$ localization in ER-ve breast cancer cells. pII cells were seeded in 8-chamber Ibid slides and allowed to grow for $48 \mathrm{~h}$ at $37^{\circ} \mathrm{C} / 5 \% \mathrm{CO}_{2}$. Cells were either untreated (control) or treated with $(\mathbf{A}) \mathrm{CoCl}_{2}$ or $(\mathbf{B}) \mathrm{DFO}(100 \mu \mathrm{M})$ for times indicated. Cells were then fixed and stained with HIF1 $\alpha$ antibody (red), phalloidin (green, to stain F-actin cytoskeleton), and DAPI (blue, to stain the nucleus), 20x magnification. Scale bar represents $20 \mu \mathrm{m}$.

increased particularly at $4-24 \mathrm{~h}$ of stimulation and declined at $48 \mathrm{~h}$ in all the cell lines (Fig. $1 \mathrm{~A}-\mathrm{C}$ ). The highest expression (by up to 4 -fold) (both at baseline and in response to $\mathrm{CoCl}_{2}$ ) was seen in the ER -ve breast cancer cells (which have a higher proliferation and migration rate in comparison to ER + breast cancer cells), with the lowest expression in the normal epithelial breast cells. DFO treatment of pII cells also enhanced HIF-1 $\alpha$ expression to similar levels (Fig. 1D).

Under hypoxic conditions, HIF $1 \alpha$ is accumulated into the nucleus ${ }^{22}$. Moroz et al. ${ }^{62}$ reported that under normoxic conditions, HIF-1a/FLuc in NIH3T3 reporter cells and HIF-1a in wild-type NIH3T3 cells was mainly localised in the cytoplasm; however, in HEK293 reporter and wild-type cells, HIF1 $\alpha$ was distributed between both cytoplasm and nucleus. Upon $\mathrm{CoCl}_{2}$ treatment $(100 \mu \mathrm{M}, 6 \mathrm{~h}) \mathrm{HIF} 1 \alpha$ was translocated to the nucleus in all the cell lines. This pattern was also observed following exposure to hypoxia $\left(2.5 \% \mathrm{O}_{2}\right)$. In MCF-7 cells, induction of hypoxia using $\mathrm{CoCl}_{2}$ treatment $(200 \mu \mathrm{M}$ for $24 \mathrm{~h})$ increased HIF1 $\alpha$ nuclear localization and up-regulation of its expression $^{63}$. In agreement with these studies, we too observed cytoplasmic HIF-1 $\alpha$ only after hypoxic exposure, with subsequent translocation to the nucleus after $24-48 \mathrm{~h}$.

Hypoxia mediated increase in cell proliferation has been reported in human hepatocellular carcinoma cultured in $1 \% \mathrm{O}_{2}$ for $36 \mathrm{~h}^{45}$ in MCF7 cells treated with $\mathrm{CoCl}_{2}$ showing a peak of proliferation at $150 \mu \mathrm{M}$ with inhibition at higher doses ${ }^{64}$ and similarly in MDA-MB-231 cells, at $25 \mu \mathrm{M}$ with higher concentrations decreasing proliferation rate ${ }^{64}$. Other reports showed decreased cell growth upon exposure to hypoxic environment. For example, Chan et al.$^{13}$ reported that $72 \mathrm{~h}$ exposure of human lung carcinoma (H1299) cells to $0.2 \% \mathrm{O}_{2}$ decreased their survival by $18 \%$, with $0 \% \mathrm{O}_{2}$ conditions leading to apoptosis. Pancreatic PC2 cancer cells were inhibited by $\mathrm{CoCl}_{2}(50-200 \mu \mathrm{M})^{46}$. Treatment of MDA-MB-231 cells with DFO $(30-300 \mu \mathrm{M}$, for $24 \mathrm{~h})$ had no effect on their proliferation rate ${ }^{61}$. In this study, we observed that $\mathrm{CoCl}_{2}$ and $\mathrm{DFO}$ treatment $(100 \mu \mathrm{M}$, for $24-96 \mathrm{~h})$ decreased both normal and breast cancer cell proliferation (Fig. 5).

Several reports have suggested a role of hypoxia in modulating cancer cell migration and invasion; knockdown of Wnt-1 induced signaling protein 2 (WISP-2) in non-invasive MCF7 cells enhanced their motility under hypoxic conditions $\left(0.2 \% \mathrm{O}_{2}, 24 \mathrm{~h}\right)^{65}$ as did treatment of MCF-7 with $\mathrm{CoCl}_{2}(200 \mu \mathrm{M}, 24 \mathrm{~h})^{63}$ and MDA-MB-231 with DFO (30-300 $\mu \mathrm{M}, 24 \mathrm{~h})$. We also demonstrated enhanced ER + ve and ER - ve cell motility (by approximately 2-fold) in response to both $\mathrm{CoCl}_{2}$ and DFO treatment (Fig. 6), in agreement with those reports. Hoffmann and colleagues have shown that hypoxia promotes mesenchymal invasion in breast cancer cells mediated through upregulation of cysteine-rich protein 2 , a component of the actin cytoskeletal machinery involved in invadopodia formation. This was also demonstrated in xenograft breast tumours in $v i v o^{66}$.

A somewhat surprising observation was that MCF10A cells were found to be highly motile. However, this was found to be largely due to the presence of EGF in their special culture medium, as they showed little movement 

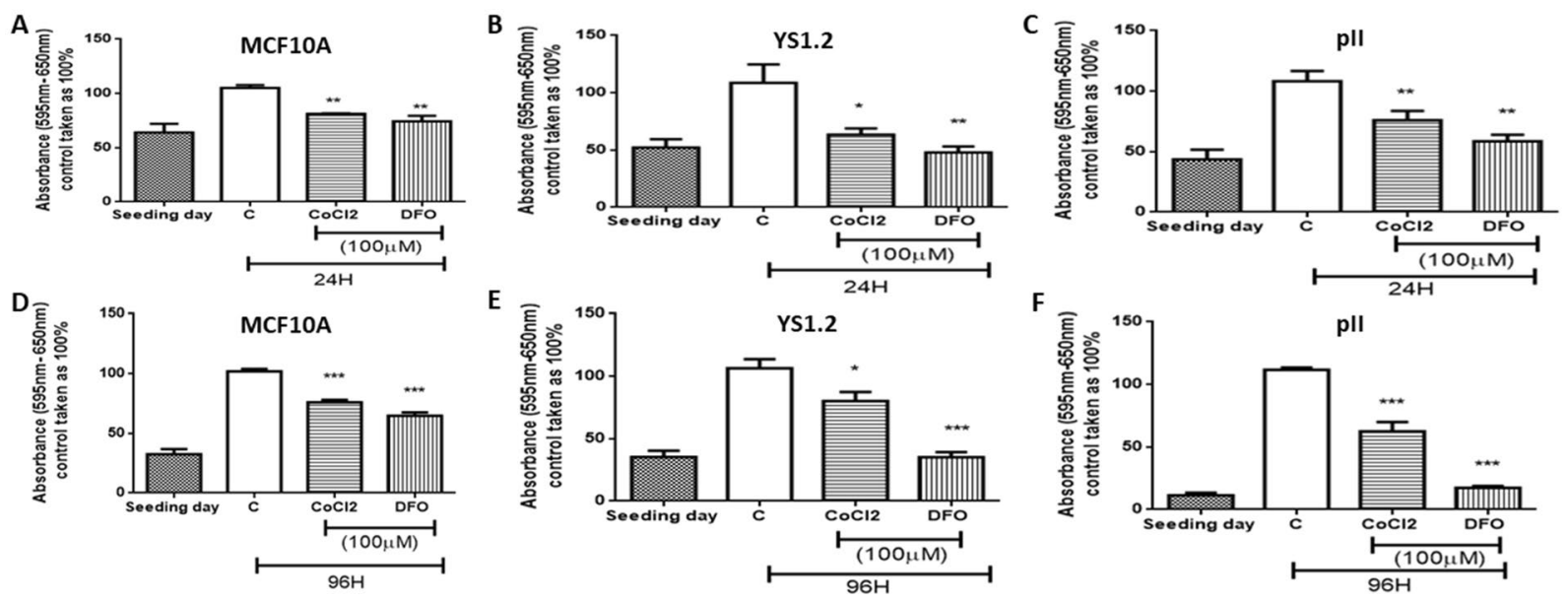

Figure 5. Effect of $\mathrm{CoCl}_{2}$ or DFO treatment on cell proliferation. Cells, as indicated, were seeded at day 1 (hatched bar) were either untreated $(\mathrm{C})$ or treated with $\mathrm{CoCl}_{2}$ or DFO $(100 \mu \mathrm{M})$ and assayed by MTT after 1 day (A-C) or 4 days (D-F). Histobars represent the mean \pm SEM of 6 independent determinations. Asterisks denote significant difference from the control, with $(*) \mathrm{p}>0.05,(* *) \mathrm{p}=0.01$, and $(* * *) \mathrm{p}=0.001$.

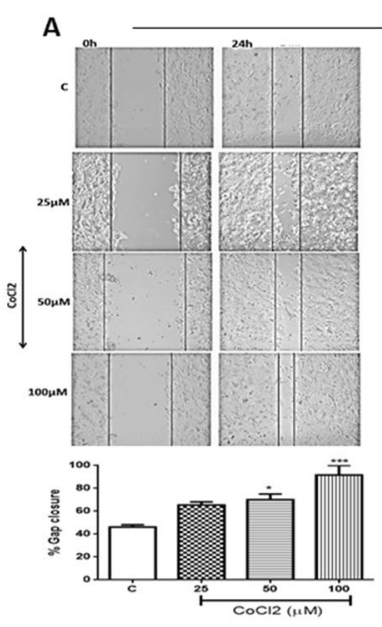

YS1.2

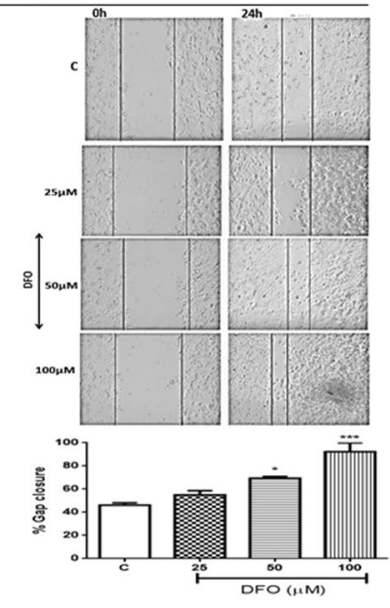

B

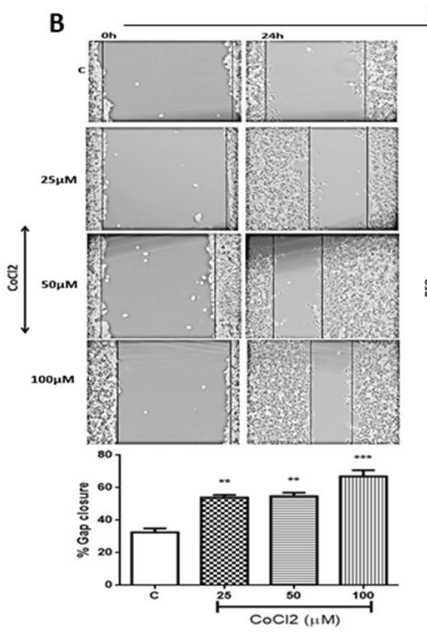

Figure 6. Effect of $\mathrm{CoCl}_{2}$ or DFO treatment on breast cancer cell motility. A scratch was made through a confluent layer of (A) YS1.2 or (B) pII cells, using a p20 (for YS1.2) or p1000 (for pII) pipette tip, and the gap measured at 0 time and after $24 \mathrm{~h}$ of $\mathrm{DFO}$ or $\mathrm{CoCl}_{2}$ treatment at the concentrations indicated, as described in Methods. The $\%$ wound closure was calculated as the width of the empty space after $24 \mathrm{~h}$ divided by the width at 0 -time $\mathrm{x} 100$ subtracted from 100. Histobars represent the mean \pm SEM of 9 independent determinations. Asterisks denote significant difference from the control, with $(*) \mathrm{p}>0.05,(* *) \mathrm{p}=0.01$, and $(* * *) \mathrm{p}=0.001$.

when this was omitted. Hypoxic conditions greatly stimulated motility irrespective of the medium used. Maeda and colleagues also observed significant motility (using same medium as ours) that was further enhanced by $\mathrm{TGF}^{67}$. An interesting aside was their finding that MCF10A exhibited cadherin switching, a phenomenon associated with EMT. Similarly, Rodriguez-Monterrosas and colleagues reported increased motility stimulated by insulin (also a component of the MCF10A medium) in association with EMT ${ }^{68}$. Vaapil and colleagues found no evidence for hypoxia-driven $\mathrm{EMT}^{69}$. Such reports have called into question the use of MCF10A as a representative of normal breast epithelia ${ }^{70}$. Or is this a cautionary indication that normal cells can exhibit some 'cancer-like' properties confronted with hypoxia or other stimulants? Either way this needs further investigation, but was not pursued here as it is not directly relevant to the objective of this study.

It was noticed that MCF7 cells treated with $\mathrm{CoCl}_{2}(200 \mu \mathrm{M}$ for $24 \mathrm{~h})$ migrated faster than control ${ }^{63}$, MDA-MB-231 cell invasion increased by $24-129 \%$ by treatment with $30-300 \mu \mathrm{M}$ of DFO for $24 \mathrm{~h}^{61}$ and hepatocellular carcinoma cells treated with $100 \mu \mathrm{M} \mathrm{CoCl}_{2}$ displayed approximately $10 \%$ increase in migration and invasion; this effect was reversed upon removal of the $\mathrm{CoCl}_{2}{ }^{71}$.In agreement with previous observations ${ }^{56,57}$, our data using the Cultrex assay (Fig. 7A,B) shows that ER - ve cells are more invasive through BME when compared to the poorly invasive ER + ve cells but with no further enhancement upon $\mathrm{CoCl}_{2}$ or DFO treatment. Random cell migration into agarose, could be seen only with ER- breast cancer cells $\mathrm{s}^{56,57}$. 
A
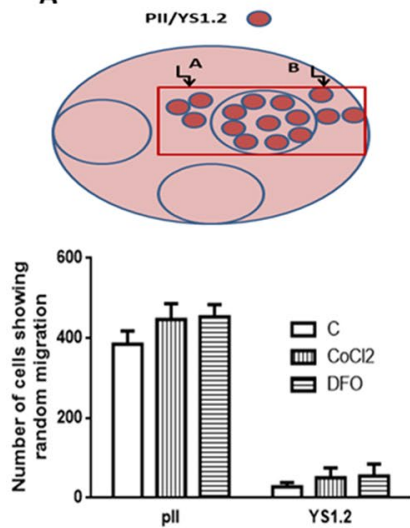

B
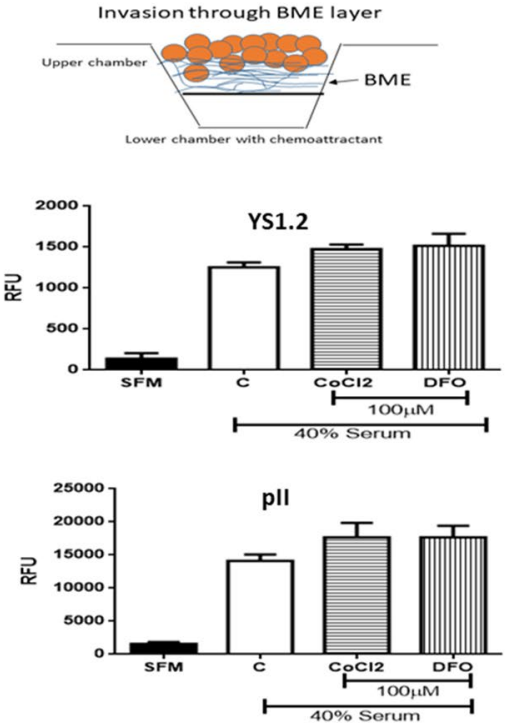

C
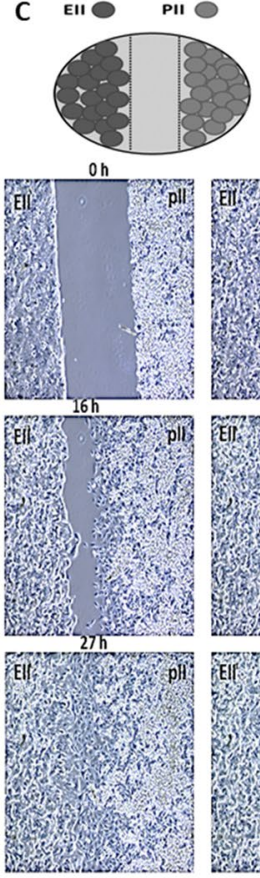
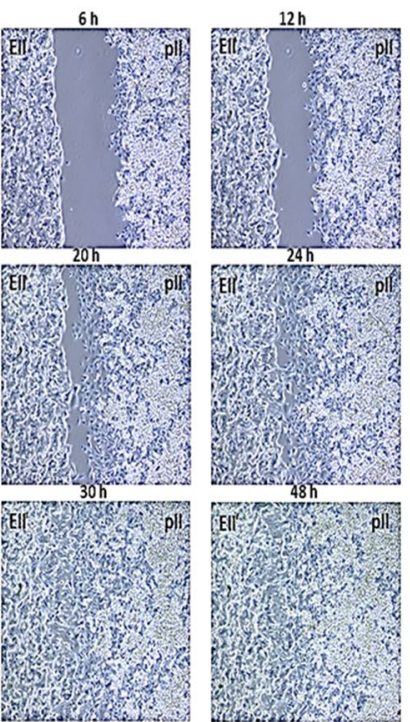

Figure 7. Effect of hypoxic simulation on the migration and invasion of breast cancer cells. Panel A: YS1.2 and pII cells were treated with either vehicle (control), or with or $\mathrm{CoCl}_{2}$ or DFO $(100 \mu \mathrm{M})$ for $24 \mathrm{~h}$. Cells were loaded into wells formed in an agarose layer in 6 well plates. The total number of cells migrating/penetrating into the agarose in both lateral directions were manually counted using an inverted microscope as described in Methods. Histobars represent mean \pm SEM of 3 independent determinations. Panel B: YS1.2 and pII cells pre-treated with vehicle (C, open bar), $\mathrm{CoCl}_{2}$ or $\mathrm{DFO}(100 \mu \mathrm{M}$, hatched bars) were loaded into the top chamber of a Cultrex dish. Cells invading through the BME layer into the lower chamber containing either serum free media (SFM, solid bar) or media containing $40 \%$ serum (used as chemoattractant) were measured as described in Methods and represented here as relative fluorescence units. Histobars represents mean \pm SEM of 6 independent determinations. Panel C: Snapshots from time-lapse photography of pII and EII cells cultured for $48 \mathrm{~h}$. Cells were seeded separately into adjacent chambers of an Ibidi chamber slide with a space between them. After $24 \mathrm{~h}$ the scaffold was removed leaving a gap between the two monolayers. The time-lapse photography showed that only the pII cells moved towards the EII cell monolayer and over $27 \mathrm{~h}$ completely closed the gap. (10x magnification). A schematic diagram explaining each experimental setup is shown on the top of each panel.

To address the issue of whether cells deeper inside a tumor could penetrate through other layers of cells to reach blood vessels, we performed two types of co-culture experiments. We observed that the ER- breast cancer cells were able to make their way into and through a solid barrier of ER + cells when cultured adjacent to each other, and were also able to make their way out from a mixture of cells into the surrounding space (Fig. 8). Hypoxic conditions induced greater number of penetrating cells as compared to the number of invasive cells under normoxic conditions. The number of cells was however very small; possibly due to lack of 'incentive' for the cells to move in any particular direction. Although the Ibidi chambers permit visualization of migrating cells they also have disadvantages in this respect. The Cultrex chamber can allow a downward gravitational movement towards a source of serum; using this assay system we observed similar results whereby ER-cells penetrated through a layer of non-invasive ER + cells and invaded through a layer of BME towards serum components. In this assay cell numbers were not counted; their presence was inferred by an indirect measure using calcein uptake. Therefore, we cannot quantitatively compare the two methods but (given that the fluorescence detection method would require a significant number of cells) it would not be unreasonable to assume that much larger numbers got through. Whilst it was observed, as would be expected, that the barrier of EII cells restricted the migration of the pII cells (Fig. 10) it is also clear that some were indeed able to move through the EII barrier. Small increase in number of invasive cells in the presence of $\mathrm{CoCl}_{2}$ was not statistically significant. Also, we were able to observe cell penetration through the other cell population only after 3-4 days of co-culture, but in the Cultrex assay, cells need to be assessed within $24 \mathrm{~h}$.

In summary, the present study attempted to construct an in vitro model to investigate the possibility that cells that are located deeper within a tumor can penetrate into and migrate through other cell layers in order to reach vascular elements present nearer to the surface of the tumor mass and metastasize. As these are likely to be in a more hypoxic environment (which has been claimed to stimulate metastasis) we performed experiments in both normoxic and hypoxic conditions. Overall our data support the idea of cancer cells metastasizing as an escape from an unfavorable environment, in this case, hypoxia. Certainly, it appears to be a characteristic behavior of cells that have undergone EMT by whatever means Currently there is no data to indicate which cells within a 
A
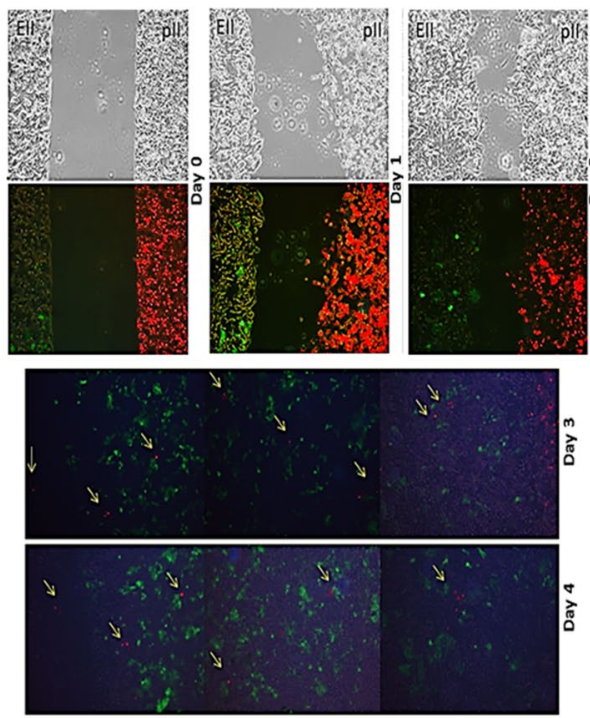

Inside Ell layer
Control
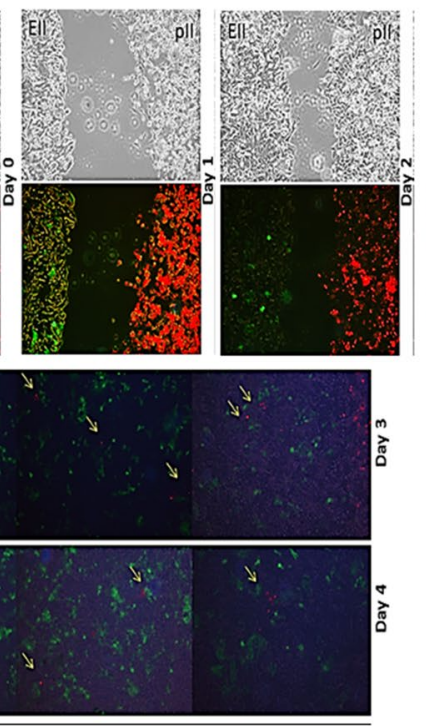

B
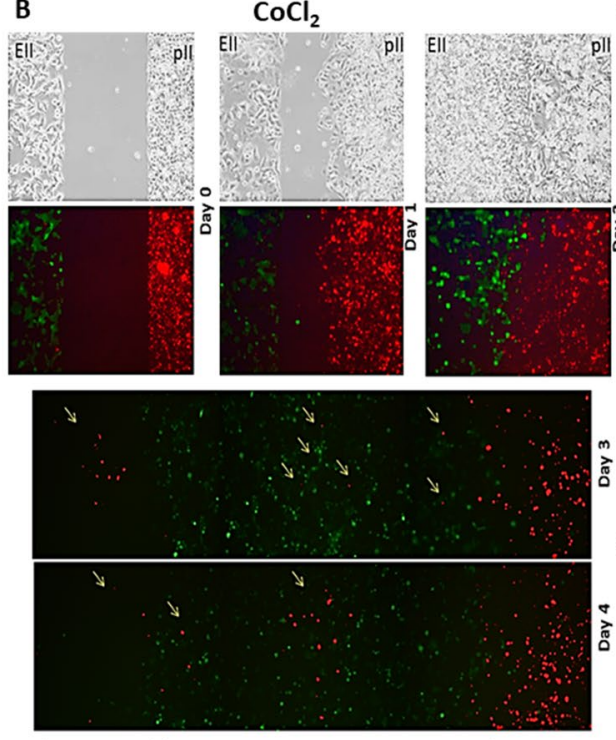

Beyond Ell layer
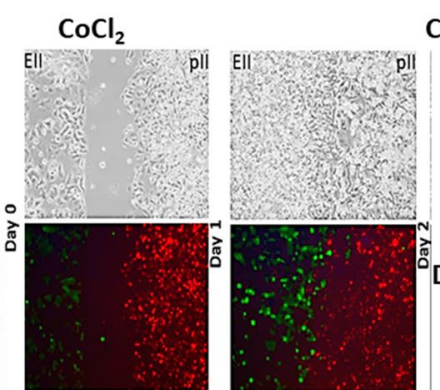

Inside Ell layer
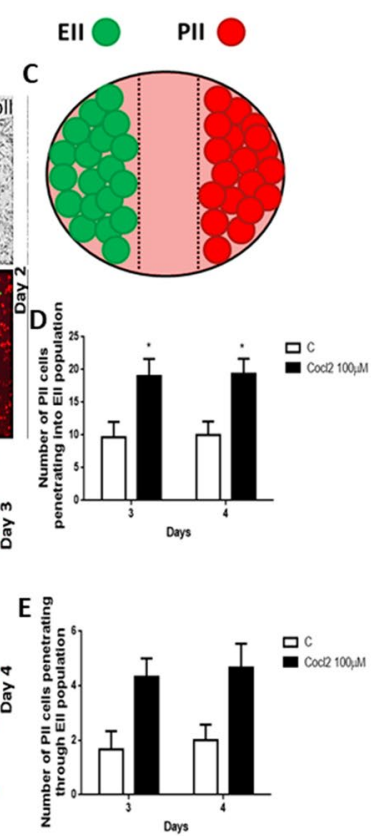

Figure 8. Culture of ER - ve and ER + ve breast cancer cells under normoxic and hypoxic condition. Cells (red; pII, green; EII) were seeded separately (at $80 \%$ confluency) into adjacent chambers of an Ibidi chamber slide with a space between them. After $24 \mathrm{~h}$ the scaffold was removed leaving a gap between the two monolayers. Cells were cultured under normoxic (panel A, control) or hypoxic conditions (panel B) for 4 days. Snap shots of the cells were taken every $24 \mathrm{~h}$; pII cells moved to close the gap (day 2) and migrate/penetrate into the EII monolayer and later a few cells penetrated through it (days 3-4). Panel C represents a schematic diagram explaining the experimental setup. The number of pII cells penetrating EII monolayer (D) or invading through the EII population (E) is shown in the histobars; this was manually observed using a fluorescence microscope. Histobars represent 3 independent determinations with $(*) p>0.05$.

A

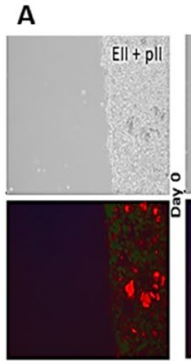

Control
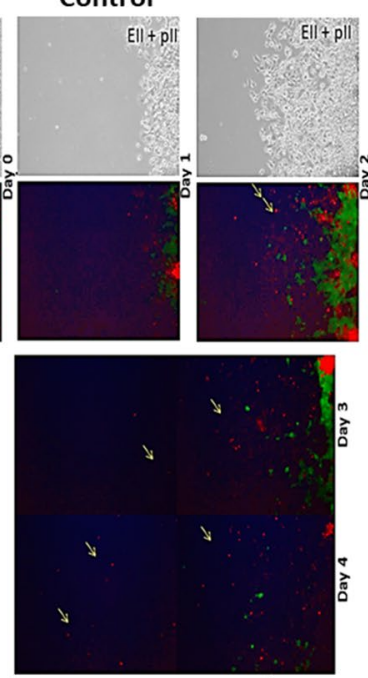

Open space
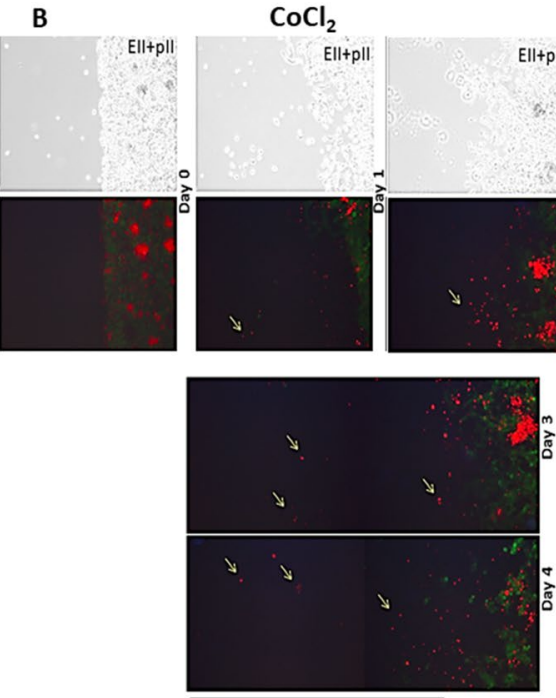

Open space

Figure 9. Effect of $\mathrm{CoCl}_{2}$ on the migration of mixed population of ER-ve and $\mathrm{ER}+$ ve breast cancer cells. Cells (red; pII, green; EII) were seeded together (at $80 \%$ confluency) into an Ibidi chamber slide. Cells were cultured under normoxic $(\mathbf{A})$ or hypoxic $\left(\mathrm{CoCl}_{2} 100 \mu \mathrm{M}\right)(\mathbf{B})$ condition for 4 days; snapshots of the cells cultured under both conditions taken every $24 \mathrm{~h}$. pII cells migrated/penetrated out of the mixture into the open space starting from day 1 of the co-culture. Panel $\mathrm{C}$ represent a schematic diagram explaining the experimental setup. Panel $\mathrm{D}$ indicates total number of pII cells (red) moving out of the mixture manually counted every $24 \mathrm{~h}$ using a fluorescent microscope. Histobars represent 3 independent determinations. Asterisks denote significant difference from the control, with $\mathrm{p}<0.05(*)$. 


\section{PII EII $\bigcirc$ BME $\sim$}

\section{Invasion through BME and cells layer}

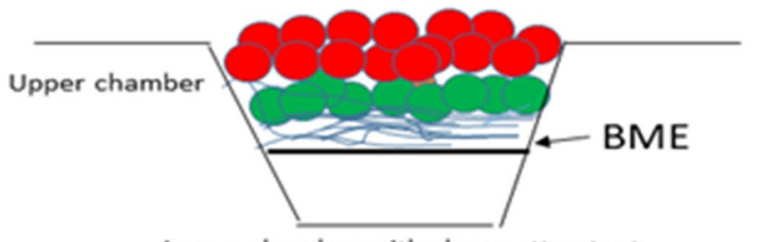

Lower chamber with chemoattractant

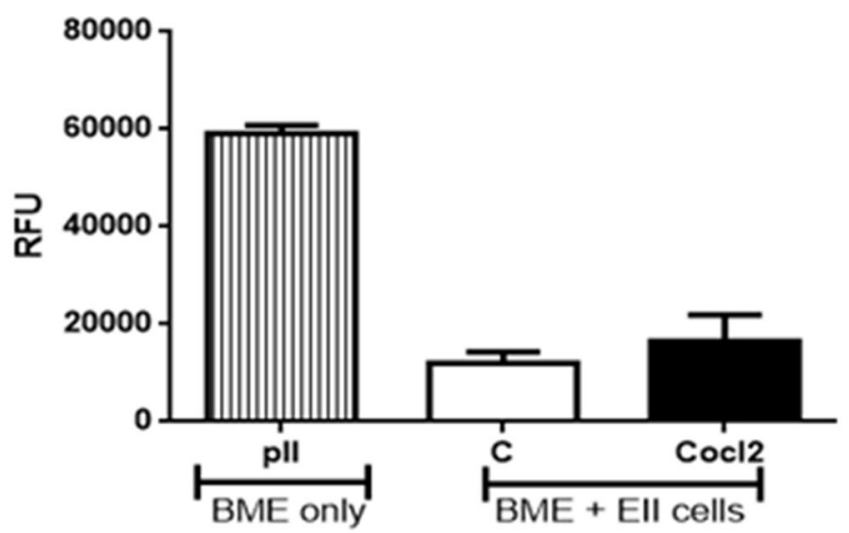

Figure 10. Effect of normoxia and hypoxia on the invasion of ER-ve breast cancer cells through either BME alone or a double layer of ER + cells and BME. Untreated pII cells were loaded into the top chamber of a Cultrex BME cell invasion plate which was previously loaded with BME only. pII cells [treated with vehicle (C) or $\mathrm{CoCl}_{2}, 100 \mu \mathrm{M}$ ] were loaded into the top chamber of a Cultrex BME cell invasion plate which was previously loaded with another layer of EII cells above the BME. pII cells invading into the lower chamber, towards serum, were detected as described in Methods. Histobars represents mean \pm SEM of 3 independent determinations. It should be noted that no EII invasion towards the lower chamber was observed. A schematic diagram explaining each experimental setup is shown on the top of the figure.

tumor undergo this transformation or where they are located. Intuitively one might expect that it should be the ones at the tumor periphery in close proximity to functional blood vessels; while this may still be the case, our data suggests that EMT transformed cells can also migrate from further inside the tumor. Also, hypoxia significantly enhances endocrine resistant breast cancer cell migration/penetration into other cell monolayers but not through BME. Translating this into an in vivo scenario, one might envisage that hypoxia could drive $\mathrm{O}_{2}$ deprived cells to migrate towards the peripheral vasculature but not necessarily aid them to intravasate into it.

The biggest limitation of our experimental approach is its two-dimensional nature and the use of pure cell populations. This could be improved with the use of three-dimensional organoid cultures with stromal elements and normal epithelial cells as well as live cell imaging of fluorescently labeled cells to track their movement in real time.

Received: 2 October 2019; Accepted: 6 January 2020;

Published online: 24 January 2020

\section{References}

1. Muz, B., de la Puente, P., Azab, F. \& Azab, A. K. The role of hypoxia in cancer progression, angiogenesis, metastasis, and resistance to therapy. Hypoxia, 3, 83-92.

2. Semenza, G. L. Hypoxia, clonal selection, and the role of HIF-1 in tumor progression. Crit. Rev. Biochem. Mol. Biol. 35, 71-103 (2000).

3. Semenza, G. L. Defining the role of hypoxia-inducible factor 1 in cancer biology and therapeutics. Oncogene 29, 625-634 (2010).

4. Semenza, G. L. Regulation of metabolism by hypoxia-inducible factor 1. Cold Spring Harb. Symp. Quant. Biol. 76, 347-353 (2011).

5. Hockel, M. et al. Association between tumor hypoxia and malignant progression in advanced cancer of the uterine cervix. Cancer Res. 56, 4509-4515 (1996).

6. Wu, M. Z. et al. Hypoxia Drives Breast Tumor Malignancy through a TET-TNFalpha-p38-MAPK Signaling Axis. Cancer Res. 75, 3912-3924 (2015).

7. Bayer, C. \& Vaupel, P. Acute versus chronic hypoxia in tumors: Controversial data concerning time frames and biological consequences. Strahlenther. Onkol. 188, 616-627 (2012).

8. Vaupel, P. \& Harrison, L. Tumor hypoxia: causative factors, compensatory mechanisms, and cellular response. Oncologist 5, 4-9 (2004).

9. Mazure, N. M. \& Pouyssegur, J. Hypoxia-induced autophagy: cell death or cell survival? Curr. Opin. Cell Biol. 22, 177-180 (2010).

10. Rouschop, K. M. et al. Autophagy is required during cycling hypoxia to lower production of reactive oxygen species. Radiother. Oncol. 92, 411-416 (2009). 
11. Hsieh, C. H. et al. NADPH oxidase subunit 4-mediated reactive oxygen species contribute to cycling hypoxia-promoted tumor progression in glioblastoma multiforme. PLoS One 6, 15 (2011).

12. Rofstad, E. K., Gaustad, J. V., Egeland, T. A., Mathiesen, B. \& Galappathi, K. Tumors exposed to acute cyclic hypoxic stress show enhanced angiogenesis, perfusion and metastatic dissemination. Int. J. Cancer 127, 1535-1546 (2010).

13. Chan, N. et al. Chronic hypoxia decreases synthesis of homologous recombination proteins to offset chemoresistance and radioresistance. Cancer Res. 68, 605-614 (2008).

14. Luoto, K. R., Kumareswaran, R. \& Bristow, R. G. Tumor hypoxia as a driving force in genetic instability. Genome Integr. 4, 2041-9414 (2013).

15. Kondo, A. et al. Hypoxia-induced enrichment and mutagenesis of cells that have lost DNA mismatch repair. Cancer Res. 61, 7603-7607 (2001).

16. Han, J. et al. Hypoxia is a Key Driver of Alternative Splicing in Human Breast Cancer Cells. Sci. Rep. 7, 017-04333 (2017).

17. Semenza, G. L. \& Wang, G. L. A nuclear factor induced by hypoxia via de novo protein synthesis binds to the human erythropoietin gene enhancer at a site required for transcriptional activation. Mol. Cell Biol. 12, 5447-5454 (1992).

18. Royds, J. A., Dower, S. K., Qwarnstrom, E. E. \& Lewis, C. E. Response of tumour cells to hypoxia: role of p53 and NFkB. Mol. Pathol. 51, 55-61 (1998).

19. Chandel, N. S. et al. Reactive oxygen species generated at mitochondrial complex III stabilize hypoxia-inducible factor-1alpha during hypoxia: a mechanism of O2 sensing. J. Biol. Chem. 275, 25130-25138 (2000).

20. Movafagh, S., Crook, S. \& Vo, K. Regulation of hypoxia-inducible factor-1a by reactive oxygen species: new developments in an old debate. J. Cell Biochem. 116, 696-703 (2015).

21. Mateo, J., Garcia-Lecea, M., Cadenas, S., Hernandez, C. \& Moncada, S. Regulation of hypoxia-inducible factor-1alpha by nitric oxide through mitochondria-dependent and -independent pathways. Biochem. J. 376, 537-544 (2003).

22. Bruick, R. K. \& McKnight, S. L. A conserved family of prolyl-4-hydroxylases that modify HIF. Sci. 294, 1337-1340 (2001)

23. Maxwell, P. H. et al. The tumour suppressor protein VHL targets hypoxia-inducible factors for oxygen-dependent proteolysis. Nat. 399, 271-275 (1999).

24. Siemeister, G. et al. Reversion of deregulated expression of vascular endothelial growth factor in human renal carcinoma cells by von Hippel-Lindau tumor suppressor protein. Cancer Res. 56, 2299-2301 (1996).

25. Zagzag, D. et al. Stromal cell-derived factor-1alpha and CXCR4 expression in hemangioblastoma and clear cell-renal cell carcinoma: von Hippel-Lindau loss-of-function induces expression of a ligand and its receptor. Cancer Res. 65, 6178-6188 (2005).

26. Guo, K. et al. Hypoxia induces the expression of the pro-apoptotic gene BNIP3. Cell Death Differ. 8, 367-376 (2001).

27. An, W. G. et al. Stabilization of wild-type p53 by hypoxia-inducible factor 1alpha. Nat. 392, 405-408 (1998).

28. Jing, S. W. et al. HIF-1alpha contributes to hypoxia-induced invasion and metastasis of esophageal carcinoma via inhibiting E-cadherin and promoting MMP-2 expression. Acta Med Okayama, 66, 399-407.

29. Krishnamachary, B. et al. Hypoxia-inducible factor-1-dependent repression of E-cadherin in von Hippel-Lindau tumor suppressornull renal cell carcinoma mediated by TCF3, ZFHX1A, and ZFHX1B. Cancer Res. 66, 2725-2731 (2006).

30. Staller, P. et al. Chemokine receptor CXCR4 downregulated by von Hippel-Lindau tumour suppressor pVHL. Nat. 425, 307-311 (2003).

31. Rezaeian, A. H. et al. A hypoxia-responsive TRAF6-ATM-H2AX signalling axis promotes HIF1alpha activation, tumorigenesis and metastasis. Nat. Cell Biol. 19, 38-51 (2017).

32. Rohwer, N. et al. HIF-1alpha determines the metastatic potential of gastric cancer cells. Br. J. Cancer 100, 772-781 (2009).

33. Badowska-Kozakiewicz, A., Sobol, M. \& Patera, J. Expression of Hypoxia-Inducible Factor lalpha in Invasive Breast Cancer with Metastasis to Lymph Nodes: Correlation with Steroid Receptors, HER2 and EPO-R. Adv Clin Exp Med, 25, 741-750.

34. Lam, S. W. et al. Angiogenesis- and Hypoxia-Associated Proteins as Early Indicators of the Outcome in Patients with Metastatic Breast Cancer Given First-Line Bevacizumab-Based Therapy. Clin. Cancer Res. 22, 1611-1620 (2016).

35. Vaupel, P. \& Mayer, A. Hypoxia in cancer: significance and impact on clinical outcome. Cancer Metastasis Rev. 26, 225-239 (2007).

36. Semenza, G. L. HIF-1 mediates metabolic responses to intratumoral hypoxia and oncogenic mutations. J. Clin. Invest. 123, 3664-3671 (2013).

37. Talks, K. L. et al. The expression and distribution of the hypoxia-inducible factors HIF-1alpha and HIF-2alpha in normal human tissues, cancers, and tumor-associated macrophages. Am. J. Pathol. 157, 411-421 (2000).

38. Mizokami, K. et al. Clinicopathologic significance of hypoxia-inducible factor 1alpha overexpression in gastric carcinomas. J. Surg. Oncol. 94, 149-154 (2006).

39. Nakanishi, K. et al. Expression of hypoxia-inducible factor-1alpha protein predicts survival in patients with transitional cell carcinoma of the upper urinary tract. Clin. Cancer Res. 11, 2583-2590 (2005).

40. Nalwoga, H., Ahmed, L., Arnes, J. B., Wabinga, H. \& Akslen, L. A. Strong Expression of Hypoxia-Inducible Factor-1alpha (HIF1alpha) Is Associated with Axl Expression and Features of Aggressive Tumors in African Breast Cancer. PLoS One 11, 2016 (2016).

41. Jin, M. S. et al. Overexpression of HIFlalpha and CAXI predicts poor outcome in early-stage triple negative breast cancer. Virchows Arch. 469, 183-190 (2016).

42. Li, M. et al. Expression of LPA2 is associated with poor prognosis in human breast cancer and regulates HIF-1alpha expression and breast cancer cell growth. Oncol Rep, 36, 3479-3487.

43. Tasharrofi, B. et al. Comparative expression analysis of hypoxia-inducible factor-alpha and its natural occurring antisense in breast cancer tissues and adjacent noncancerous tissues. Cell Biochem. Funct. 34, 572-578 (2016).

44. Goldberg, M. A. \& Schneider, T. J. Similarities between the oxygen-sensing mechanisms regulating the expression of vascular endothelial growth factor and erythropoietin. J. Biol. Chem. 269, 4355-4359 (1994).

45. Gwak, G. Y. et al. Hypoxia stimulates proliferation of human hepatoma cells through the induction of hexokinase II expression. J. Hepatol. 42, 358-364 (2005).

46. Dai, Z. J. et al. Up-regulation of hypoxia inducible factor-1alpha by cobalt chloride correlates with proliferation and apoptosis in PC-2 cells. J. Exp. Clin. Cancer Res. 31, 1756-9966 (2012).

47. Steinmetz, W. L., Glick, M. R. \& Oei, T. O. Modified aca method for determination of iron chelated by deferoxamine and other chelators. Clin. Chem. 26, 1593-1597 (1980).

48. Theriault, J. R. et al. Discovery of a new molecular probe ML228: an activator of the hypoxia inducible factor (HIF) pathway. Bioorg Med. Chem. Lett. 22, 76-81 (2012)

49. Jaakkola, P. et al. Targeting of HIF-alpha to the von Hippel-Lindau ubiquitylation complex by O2-regulated prolyl hydroxylation. Sci. 292, 468-472 (2001).

50. Kilic, T., Valinhas, A. T. S., Wall, I., Renaud, P. \& Carrara, S. Label-free detection of hypoxia-induced extracellular vesicle secretion from MCF-7 cells. Sci. Rep. 8, 018-27203 (2018).

51. Azab, A. K. et al. Hypoxia promotes dissemination of multiple myeloma through acquisition of epithelial to mesenchymal transitionlike features. Blood 119, 5782-5794 (2012).

52. Muz, B., de la Puente, P., Azab, F., Ghobrial, I. M. \& Azab, A. K. Hypoxia promotes dissemination and colonization in new bone marrow niches in Waldenstrom macroglobulinemia. Mol. Cancer Res. 13, 263-272 (2015).

53. Marie-Egyptienne, D. T., Lohse, I. \& Hill, R. P. Cancer stem cells, the epithelial to mesenchymal transition (EMT) and radioresistance: potential role of hypoxia. Cancer Lett. 341, 63-72 (2013). 
54. Wang, L., Fan, J., Yan, C. Y., Ling, R. \& Yun, J. Activation of hypoxia-inducible factor-1alpha by prolonged in vivo hyperinsulinemia treatment potentiates cancerous progression in estrogen receptor-positive breast cancer cells. Biochem. Biophys. Res. Commun. 2017, 30604-30606 (2017).

55. Luqmani, Y. A., Al Azmi, A., Al Bader, M., Abraham, G. \& El Zawahri, M. Modification of gene expression induced by siRNA targeting of estrogen receptor alpha in MCF7 human breast cancer cells. Int. J. Oncol. 34, 231-242 (2009).

56. Al Saleh, S., Al Mulla, F. \& Luqmani, Y. A. Estrogen receptor silencing induces epithelial to mesenchymal transition in human breast cancer cells. PLoS One 6, 21 (2011).

57. Khajah, M. A., Al Saleh, S., Mathew, P. M. \& Luqmani, Y. A. Differential effect of growth factors on invasion and proliferation of endocrine resistant breast cancer cells. PLoS One 7, 30 (2012).

58. Daly, C. S. et al. Hypoxia modulates the stem cell population and induces EMT in the MCF-10A breast epithelial cell line. Oncol. Rep. 39, 483-490 (2018).

59. Rundqvist, H. \& Johnson, R. S. Tumour oxygenation: implications for breast cancer prognosis. J. Intern. Med. 274, 105-112 (2013).

60. Semenza, G. L. HIF-1: mediator of physiological and pathophysiological responses to hypoxia. J. Appl. Physiol. 88, 1474-1480 (1985).

61. Liu, Y. et al. Deferoxamine promotes MDA-MB-231 cell migration and invasion through increased ROS-dependent HIF-1alpha accumulation. Cell Physiol. Biochem. 33, 1036-1046 (2014).

62. Moroz, E. et al. Real-time imaging of HIF-1alpha stabilization and degradation. PLoS One 4, 4 (2009).

63. Li, S., Wei, Q., Li, Q., Zhang, B. \& Xiao, Q. Down-regulating HIF-1alpha by lentivirus-mediated shRNA for therapy of triple negative breast cancer. Cancer Biol. Ther. 16, 866-875 (2015).

64. Rana, N. K., Singh, P. \& Koch, B. CoCl2 simulated hypoxia induce cell proliferation and alter the expression pattern of hypoxia associated genes involved in angiogenesis and apoptosis. Biol. Res. 52, 019-0221 (2019).

65. Fuady, J. H. et al. Hypoxia-inducible factor-mediated induction of WISP-2 contributes to attenuated progression of breast cancer. Hypoxia 2, 23-33 (2014).

66. Hoffmann, C. et al. Hypoxia promotes breast cancer cell invasion through HIF-1alpha-mediated up-regulation of the invadopodial actin bundling protein CSRP2. Sci. Rep. 8, 018-28637 (2018).

67. Maeda, M., Johnson, K. R. \& Wheelock, M. J. Cadherin switching: essential for behavioral but not morphological changes during an epithelium-to-mesenchyme transition. J. Cell Sci. 118, 873-887 (2005).

68. Rodriguez-Monterrosas, C., Diaz-Aragon, R., Leal-Orta, E., Cortes-Reynosa, P. \& Perez Salazar, E. Insulin induces an EMT-like process in mammary epithelial cells MCF10A. J. Cell Biochem. 119, 4061-4071 (2018).

69. Vaapil, M. et al. Hypoxic conditions induce a cancer-like phenotype in human breast epithelial cells. PLoS One 7, 28 (2012).

70. Qu, Y. et al. Evaluation of MCF10A as a Reliable Model for Normal Human Mammary Epithelial Cells. PLoS One, 10 (2015).

71. Zhang, L. et al. Hypoxia induces epithelial-mesenchymal transition via activation of SNAI1 by hypoxia-inducible factor -1alpha in hepatocellular carcinoma. BMC Cancer 13, 1471-2407 (2013).

\section{Acknowledgements}

This work was supported by Kuwait University College of Graduate Studies and the Research Sector (grant No. YP03/17). Parts of this work were supported by grant SRUL02/13 to the Research Unit for Genomics, Proteomics and Cellomics Studies (OMICS), Kuwait University. We would like to thank Ms Sarah Khushaish for technical assistance with the MCF10A motility experiments.

\section{Author contributions}

Conceived and designed the experiments: M.A.K., Y.A.L. Performed the experiments: N.H.B., M.A.K. Analyzed the data: N.H.B., M.A.K., Y.A.L. Contributed reagents/materials/analysis tools: Y.A.L., M.A.K. Wrote the paper: N.H.B., M.A.K., Y.A.L.

\section{Competing interests}

The authors declare no competing interests.

\section{Additional information}

Supplementary information is available for this paper at https://doi.org/10.1038/s41598-020-58055-X.

Correspondence and requests for materials should be addressed to Y.A.L.

Reprints and permissions information is available at www.nature.com/reprints.

Publisher's note Springer Nature remains neutral with regard to jurisdictional claims in published maps and institutional affiliations.

(c) (i) Open Access This article is licensed under a Creative Commons Attribution 4.0 International

License, which permits use, sharing, adaptation, distribution and reproduction in any medium or format, as long as you give appropriate credit to the original author(s) and the source, provide a link to the Creative Commons license, and indicate if changes were made. The images or other third party material in this article are included in the article's Creative Commons license, unless indicated otherwise in a credit line to the material. If material is not included in the article's Creative Commons license and your intended use is not permitted by statutory regulation or exceeds the permitted use, you will need to obtain permission directly from the copyright holder. To view a copy of this license, visit http://creativecommons.org/licenses/by/4.0/.

(C) The Author(s) 2020 